The Cryosphere, 4, 13-20, 2010

www.the-cryosphere.net/4/13/2010/

(c) Author(s) 2010. This work is distributed under

the Creative Commons Attribution 3.0 License.

\title{
Reduced glacier sliding caused by persistent drainage from a subglacial lake
}

\author{
E. Magnússon ${ }^{1,2,3}$, H. Björnsson ${ }^{1}$, H. Rott $^{2}$, and F. Pálsson ${ }^{1}$ \\ ${ }^{1}$ Institute of Earth Sciences, University of Iceland, Sturlugata 7 - Askja, 101 Reykjavík, Iceland \\ ${ }^{2}$ Institute of Meteorology and Geophysics, University of Innsbruck, Innrain 52, 6020 Innsbruck, Austria \\ ${ }^{3}$ The Nordic Volcanological Center, Institute of Earth Sciences, University of Iceland, \\ Sturlugata 7 - Askja, 101 Reykjavík, Iceland
}

Received: 8 July 2009 - Published in The Cryosphere Discuss.: 6 August 2009

Revised: 21 December 2009 - Accepted: 29 December 2009 - Published: 15 January 2010

\begin{abstract}
We present velocity observations of a glacier outlet in Vatnajökull, Iceland, deduced from interferometric SAR (InSAR) data obtained during the ERS1/2 tandem mission in 1995-2000. More than a 50\% decrease in glacier velocity was observed subsequent to a large jökulhlaup from the subglacial lake Grímsvötn in 1996. The glacier had not reached its former flow rate in 2000. The jökulhlaup damaged the lake's ice-dam causing persistent drainage from the lake. InSAR based studies of water accumulation within Grímsvötn suggest that a leakage of $>3 \mathrm{~m}^{3} \mathrm{~s}^{-1}$ prevailed throughout our study period. We suggest that the lake leakage kept open a tunnel at low water pressure underneath the whole length of the glacier. The tunnel flow drained water from its surroundings, hence lowering the water pressure of a distributed drainage system, underneath the upper and centre parts of the glacier, which prior to the jökulhlaup sustained significant basal sliding. This is in accordance with theoretical prediction that tunnel flow in a steady state may cause slow-down in glacier velocity by reducing the subglacial water pressure. The width of the affected areas was $\sim 5 \mathrm{~km}$ on the upper part of the glacier and $\sim 8 \mathrm{~km}$ on the centre part of the glacier. This indicates that the water pressure reduction propagates laterally from the tunnel over a distance of a few $\mathrm{km}$.
\end{abstract}

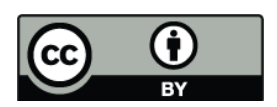

Correspondence to: E. Magnússon (eyjolfm@raunvis.hi.is)

\section{Introduction}

Variations in glacier velocity through basal sliding are generally associated with changes in the water pressure at the glacier bed (e.g. Paterson, 2006). These variations may be seasonal (e.g. Willis, 1995), diurnal (Iken, 1978; Bartholomaus et al., 2008) or related to short term events such as heavy rainfall (e.g. Sugiyama and Gudmundsson, 2004) and occasional glacier outburst floods (jökulhlaups) (e.g. Anderson et al., 2005). Studies relating water pressure and the ice motion commonly describe point measurements of GPS and simultaneous water pressure measurements at discrete boreholes (e.g. Sugiyama and Gudmundsson, 2004). Interferometric SAR (InSAR), provides a large-scale spatial overview of surface displacement. When combined with observed water discharge at the glacier margin (or other indirect information on the subglacial water flow), these data may provide information for exploring processes in the subglacial drainage system. This has been described by Magnússon et al. (2007), who studied changes in the ice flow field of Vatnajökull, Iceland (Fig. 1), during jökulhlaups from subglacial lakes. The study revealed significant and widespread acceleration in the glacier velocity during the initial phase of a jökulhlaup. Here the focus remains on the drainage from a subglacial lake and how this drainage affects glacier velocity, applying the ERS1/2 tandem data in 1995 to 2000 with $24 \mathrm{~h}$ repeat observations. We present velocity observations deduced from the InSAR data, which show significant and long-lasting reduction in basal sliding above the subglacial water course from the subglacial lake Grímsvötn subsequent to a large jökulhlaup in November 1996 that damaged the hydraulic seal of the lake's ice dam leading to continuous leakage out of the

Published by Copernicus Publications on behalf of the European Geosciences Union. 


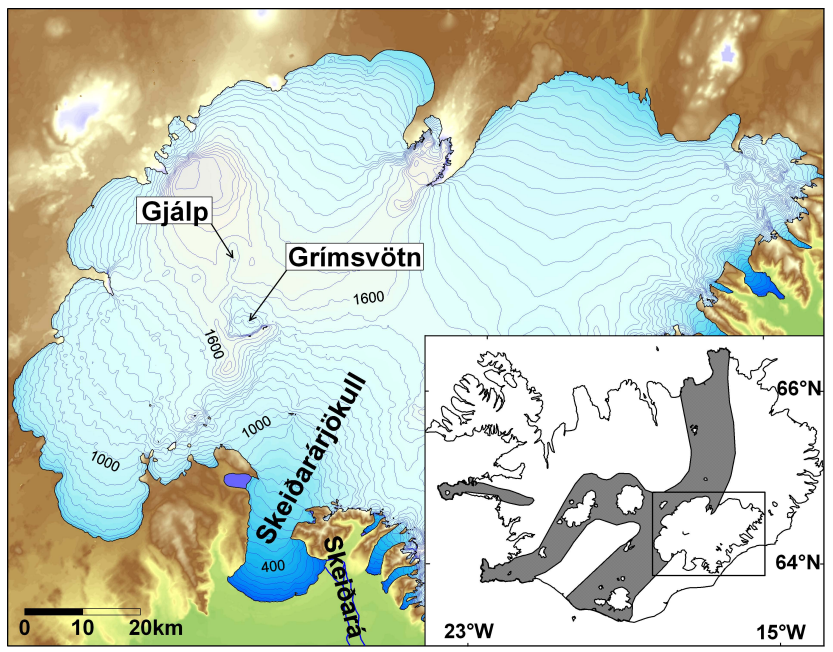

Fig. 1. Map of the Vatnajökull ice cap. The volcanic zones of Iceland are shown in grey in the inset.

lake (Björnsson, 2002). The leakage and the reduced glacier velocity prevailed throughout our study period of four years. We suggest that the continuous leakage kept open a tunnel at low water pressures (cf. Röthlisberger, 1972) preventing the development of a distributed high pressure drainage system (cf. Kamb, 1987; Walder, 1986), hence, reducing the basal sliding in the area down-glacier from the lake.

\section{Data and methods}

Comprehensive InSAR data of Vatnajökull (Fig. 1) were obtained during the ERS1/2 tandem mission in 1995-2000. A repeat-pass satellite InSAR image reveals the difference in distance in the direction of radar illumination (also referred to as line of sight or LOS) between two radar images, acquired from two similar satellite positions (Hanssen, 2001). The relative change in LOS-distance across the image is measured in terms of the coherent phase difference between the two images. The phase difference includes contributions due to surface topography, surface motion and temporal changes of atmospheric propagation properties, mainly related to water vapour. In high latitudes with low water vapour content the atmospheric contribution is usually rather small. For motion analysis the topographic phase contribution needs to be subtracted. In our case this is achieved by calculating the topographic phase using an accurate digital elevation model (DEM) and knowing the precise position of the satellites (Hanssen, 2001). The surface velocity in the LOS-direction, $v_{\text {LOS }}$, over the time period $\Delta t$ between two radar observations, is derived from the residual phase difference $\varphi$ by using:

$v_{\mathrm{LOS}}=-\frac{\lambda \varphi}{4 \pi \Delta t}$
A phase shift of $2 \pi$ (one colour-cycle (fringe) in Fig. 4) corresponds to displacement in the LOS-direction equal to half the radar wavelength $(\lambda / 2=2.83 \mathrm{~cm}$ for the ERS satellites). The contribution of three dimensional surface velocity, $\mathbf{V}=\left[v_{\mathrm{e}}, v_{\mathrm{n}}, v_{\mathrm{u}}\right](e, n$ and $u$ stand for east, north and up), to the LOS-velocity is given by:

$v_{\mathrm{e}} \cos \phi \sin \theta+v_{\mathrm{n}} \sin \phi \sin \theta-v_{\mathrm{u}} \cos \theta=v_{\mathrm{LOS}}$

where $\theta$ is the off-nadir angle and $\phi$ is the azimuth angle (relative to the north direction) of the radar beam.

The study focuses on two areas, the subglacial lake Grímsvötn (Fig. 4) and the glacier outlet Skeiðarárjökull (Fig. 2), underneath which water drains from the lake Grímsvötn. The InSAR data of Grímsvötn was topographically corrected with a DEM obtained in 1998 (Magnússon et al., 2005). For data obtained in 1995-1996 the DEM was modified based on GPS observations from that time. The InSAR data of the upper part of the area (Fig. 2) was corrected with the DEM from 1998. For the lower part we used DEMs derived by applying linear interpolation/extrapolation with time, using DEMs from 1997 (Bacher et al., 1998) and 2004 (Berthier et al., 2006) as constrains. InSAR scenes of Skeiðarárjökull obtained during summers were corrected further to compensate for the impact of surface lowering due to ablation, using a degree-day ablation model and temperature from a weather station $20 \mathrm{~km}$ southeast of Skeiðarárjökull (data from the Icelandic Meteorological Office), projected with a temperature lapse-rate of $0.006^{\circ} \mathrm{C} \mathrm{m}^{-1}$. The remaining error in the derived LOS-displacement, mostly due to temporal changes of atmospheric propagation properties, is estimated at less than $1.4 \mathrm{~cm}$ (half a fringe).

Velocity fields of the glacier outlet Skeiðarárjökull are obtained from the InSAR data. First a reference velocity field $\left(\mathbf{V}_{\text {ref }}\right)$ for the Skeiðarárjökull outlet (Fig. 2a) is deduced by combining the LOS-velocity (described by Eq. 2) derived from two ascending and two descending InSAR scenes with the mass continuity equation (Reeh et al., 2003; Magnússon et al., 2007). To calculate the velocity field at other times (Fig. 2b-e and Fig. 3) we use single InSAR scenes, showing LOS-displacement over $24 \mathrm{~h}$, combined with the mass continuity equation and the horizontal flow direction from $\mathbf{V}_{\text {ref }}$ (Magnússon et al., 2007).

The InSAR data are also used to obtain the net water accumulation within the lake Grímsvötn (Fig. 5). This is done by integrating the interpreted vertical displacement of the floating part of Grímsvötn ice cover. Insignificant horizontal surface motion is expected within these lake areas. Counting the number of fringes within the floating part of the ice cover therefore reveals the approximate $24 \mathrm{~h}$ vertical displacement. One fringe corresponds to vertical displacement of $\sim 3 \mathrm{~cm}$ in $24 \mathrm{~h}$ (derived from Eq. 2). The uncertainty in the volume estimates are due to possible phase noise in the interferograms, misinterpretation of horizontal motion as vertical, interpolation of data gaps, and possible subglacial melting of the floating ice cover, which is not separately monitored by InSAR. 

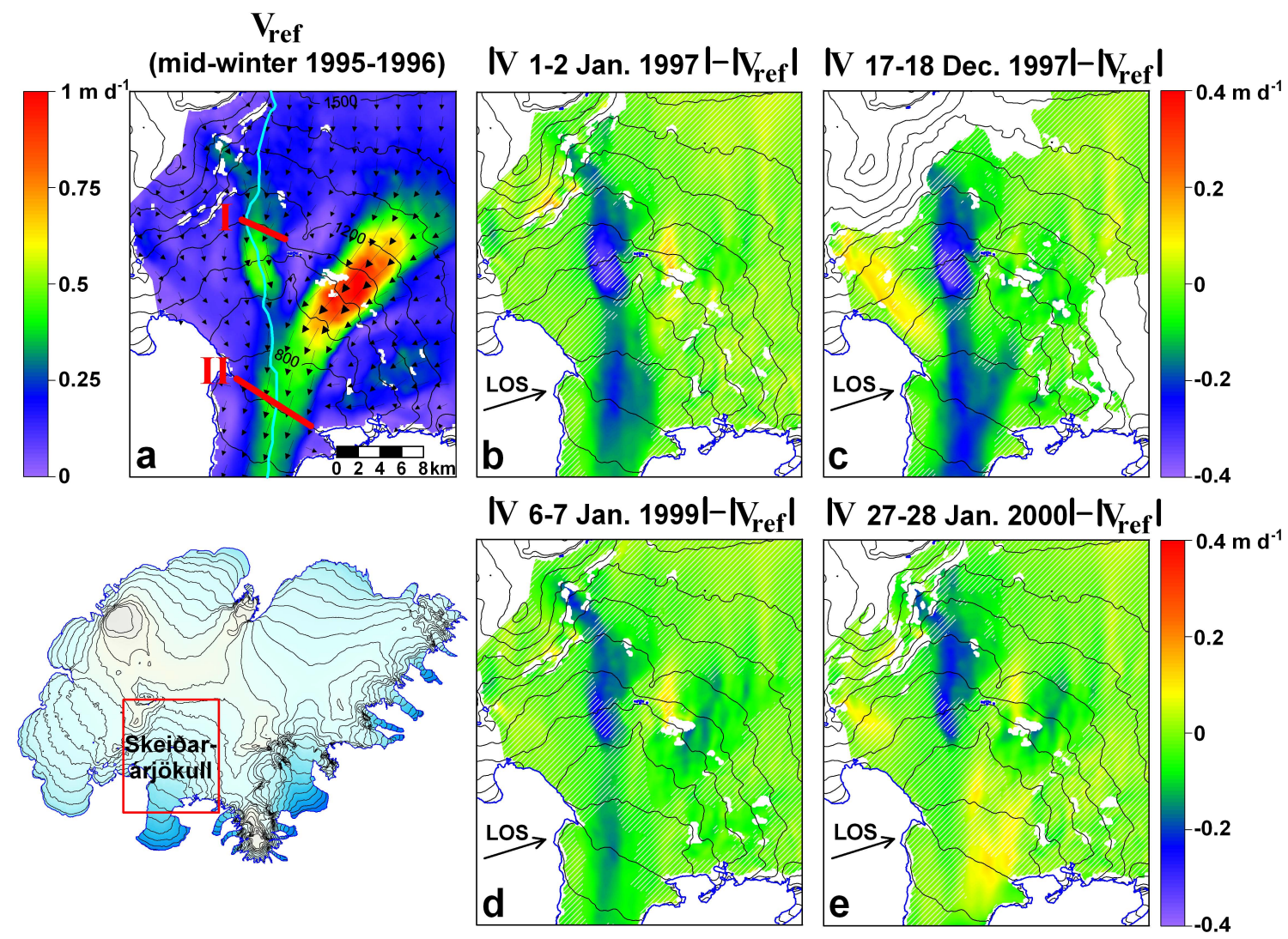

Fig. 2. (a) The horizontal velocity field $\mathbf{V}_{\text {ref }}$ during mid-winter 1995-1996. Contours show elevation based on DEMs from 1996-1998 (Magnússon, 2008; Bacher et al., 1999; Magnússon et al., 2005). The light blue line shows the estimated flow route from Grímsvötn. Velocities on the two cross sections are shown in Fig. 3. (b-e) The change in horizontal velocity relative to $\mathbf{V}_{\text {ref }}$ with approximately one year interval from January 1997 to January 2000. The hatched regions indicate areas where the difference in LOS-velocity relative to $\mathbf{V}_{\text {ref }}$ corresponds to less than half a fringe $\left(1.4 \mathrm{~cm} \mathrm{~d}^{-1}\right)$. These are areas were the impact of processing noise may be significant in relation to the derived velocity change. Radar line of sight (LOS) is indicated with an arrow.

\section{Observations}

\subsection{Glacier surface velocity fields derived from InSAR}

Our analysis focuses at the central and upper parts of the Skeiðarárjökull glacier. InSAR data show a rather stable velocity field for Skeiðarárjökull in 1995-1996 prior to the Gjálp eruption in November 1996. The few exceptions are related to intense rain or jökulhlaup (Magnússon et al., 2007). The variability is highest near the glacier terminus, outside our study area. Our reference velocity field $\left(\mathbf{V}_{\text {ref }}\right.$, Fig. 2a) is based on four InSAR scenes obtained between the end of December 1995 and the beginning of February 1996, and is representative for the velocity field of the glacier outlet during this winter. In the upper part we do not observe much seasonal variability, but farther down-glacier the glacier motion appears slightly higher during summers (Fig. 3).

Our velocity record subsequent to the Gjálp eruption shows the horizontal surface displacement over $24 \mathrm{~h}$ for discrete dates in the period from January 1997 until Febru- ary 2000 (Figs. 2-3). It shows that subsequent to the large jökulhlaup in 1996, the horizontal velocity of the glacier section below which water drains from Grímsvötn was reduced by $>50 \%$ (Fig. 3). The velocity of this glacier section remained low throughout the study period, both during summers and winters. Further down-glacier this ice stream joins the main Skeiðarárjökull glacier outlet. On a crosssection over the main glacier outlet, above the flow route from Grímsvötn, the horizontal velocity was reduced by half after the jökulhlaup (Fig. 3). It remained low the first year, even during the summer but gradually evolved to its former state during the study period. At the end of the period in 2000 the glacier motion did not differ significantly from our observations prior to the Gjálp eruption.

\subsection{Observations of lake drainage}

The subglacial lake Grímsvötn is located in a caldera above Iceland's most active central volcano. Water, produced by geothermal and volcanic activity as well as surface melting, 

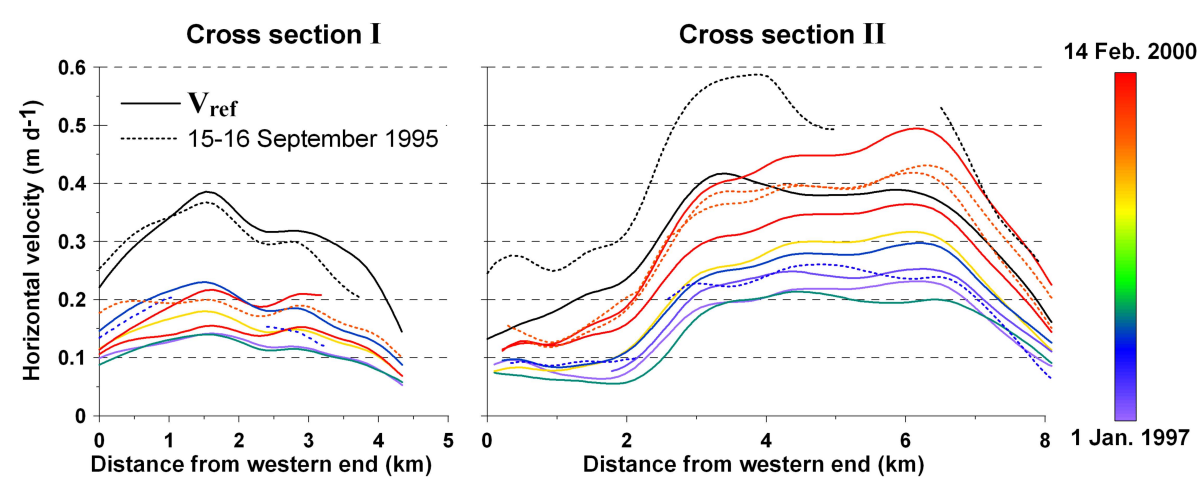

Fig. 3. The horizontal surface velocity on two cross sections on Skeiðarárjökull (locations shown in Fig. 2a) derived from InSAR data for various dates. The time for each measurement after the Gjálp eruption is given with the colour bar. Scenes from June-September, which may show higher velocity due to seasonal variability, are shown with dotted lines. Radar LOS is approximately the same for all the measurements as shown in Fig. $2 b-e$.

accumulates in the lake, which in the second half of the 20th century led to jökulhlaups at intervals of 1-10 year (Björnsson, 2002). Until 1996 the lake was sealed by an ice dam preventing drainage between jökulhlaups. This allows the total volume of each jökulhlaup to be used as a natural calorimeter for evaluating the heat output of the subglacial geothermal system (Björnsson and Gudmundsson, 1993). This approach gives an estimated power of $1.9 \mathrm{GW}$ for the period 19911996 (Magnússon, 2008).

The drainage pattern of Grímsvötn changed significantly in the autumn 1996 following the Gjálp subglacial eruption, $12 \mathrm{~km}$ north of Grímsvötn (Fig. 4c). Over a period of a month more than $3 \mathrm{~km}^{3}$ of melt water produced by the eruption and the subsequent cooling of the Gjálp edifice accumulated in the Grímsvötn subglacial lake (Gudmundsson et al., 1997). The water accumulation led to hydrostatic uplift of the ice dam sealing Grímsvötn, causing a jökulhlaup (Björnsson, 2002). It lasted for 2 days with peak flow from the lake of $40000 \mathrm{~m}^{3} \mathrm{~s}^{-1}$. By the end of the jökulhlaup, water from the Gjálp edifice accumulated for few weeks in Grímsvötn but after that the lake level subsided until the spring of 1997 because water drained from the lake through a trench, formed during the jökulhlaup, cutting through the ice dam of Grímsvötn (Björnsson, 2002).

In the spring 1997 water started to accumulate again in Grímsvötn and until the end of the year 1999 three minor jökulhlaups occurred. The total amount of water draining in these jökulhlaups was $\sim 0.9 \mathrm{~km}^{3}$, estimated from discrete GPS elevation measurement on the centre of the Grímsvötn ice cover and known relation between the elevation and the water storage of Grímsvötn (Institute of Earth Sciences data). Estimated water inflow to the lake during that time was $\sim 1.6 \mathrm{~km}^{3}$. This value includes four components: a) surface melt water $\left(\sim 0.7 \mathrm{~km}^{3}\right.$, Magnússon, 2008), b) subglacial melt from the Gjálp edifice $\left(\sim 0.35 \mathrm{~km}^{3}\right.$, Jarosch et al., 2008), c) meltwater produced by an eruption within the caldera in 1998 $\left(0.15 \mathrm{~km}^{3}\right.$, Gudmundsson, 2005) and d) meltwater produced by geothermal activity in the Grímsvötn area $\left(\sim 0.45 \mathrm{~km}^{3}\right.$, derived by assuming the same geothermal power of the area as in 1991-1996). The difference between the derived inflow and outflow via jökulhlaups gives a rough estimate on the volume of water draining from the lake between the jökulhlaups. It corresponds to an outflow of $\sim 9 \mathrm{~m}^{3} \mathrm{~s}^{-1}$ averaged over the period. It is however not possible to determine solely from the discrete GPS data if the drainage was continuous or occurred in several short events.

InSAR data from 1995-1996, prior to the Gjálp eruption, show seasonal variations in the water accumulation rate in Grímsvötn due to changes in surface melt rate. The dataset indicates that the water accumulation rate started increasing in June and exceeded $30 \mathrm{~m}^{3} \mathrm{~s}^{-1}$ during the summer. Throughout the autumn it remained high and was still $17 \mathrm{~m}^{3} \mathrm{~s}^{-1}$ in late October 1995, which indicates inefficient transport of melt water to the lake (values derived in the same way as in Fig. 5). In December the accumulation rate seems to have reached the winter minimum between 4 and $8 \mathrm{~m}^{3} \mathrm{~s}^{-1}$. The average of the InSAR-deduced winter values for Grímsvötn before the Gjálp eruption is $6 \mathrm{~m}^{3} \mathrm{~s}^{-1}$. The power needed to maintain this melt rate corresponds to $2.0 \mathrm{GW}$, slightly higher than the estimated power of $1.9 \mathrm{GW}$ for the period 1991-1996.

For 1-2 January (Fig. 4a) and 12-13 March 1997 the InSAR data show, in accordance with field observation, water depletion in Grímsvötn, despite significant drainage from the Gjálp edifice (Gudmundsson et al., 2002). After this we observe from the InSAR data either uplift in Grímsvötn due to water accumulation or insignificant change. We still observe seasonal variability in the water accumulation in Grímsvötn but in general the net water accumulation is lower for a given time of the year after the Gjálp eruption than for the same time of the year prior to it, indicating that Grímsvötn leaked continuously from 1997 throughout our study period.

The estimated change in water accumulation rate in Grímsvötn is most reliable in the winter time (Fig. 5) when 


\section{Mean(27-28 Dec. 1995 \& 29-30 Dec. 1995)}

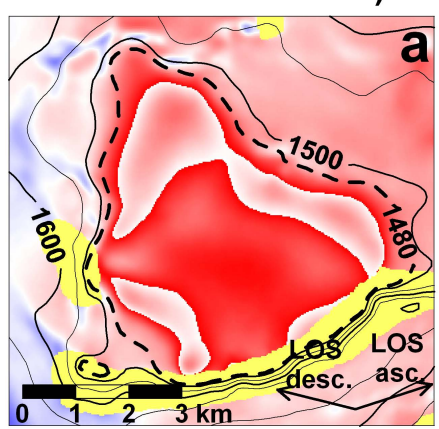

1-2 Jan. 1997

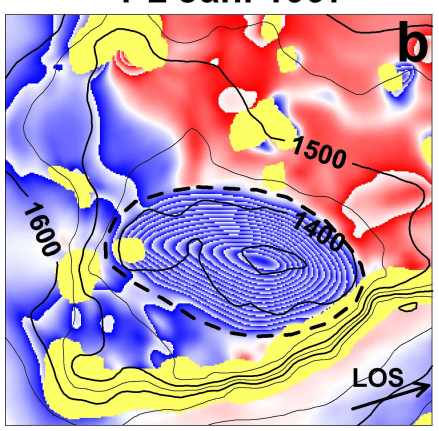

\section{6-7 January 1999}

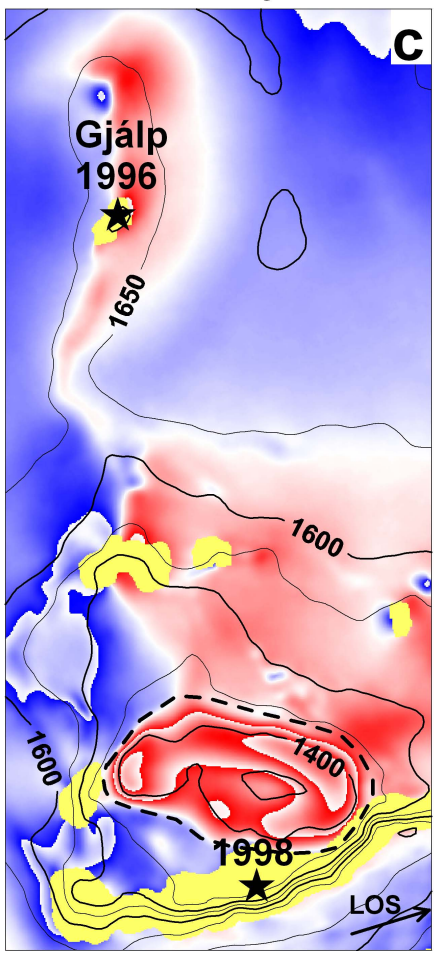

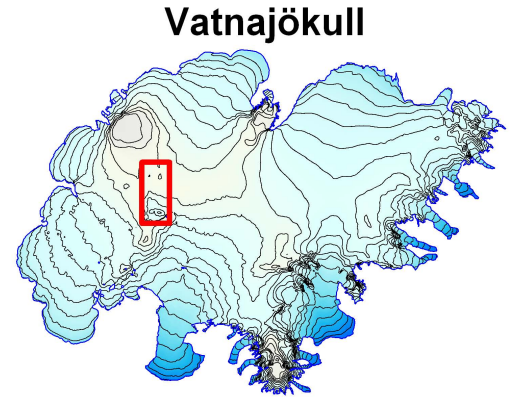

14-15 February 2000

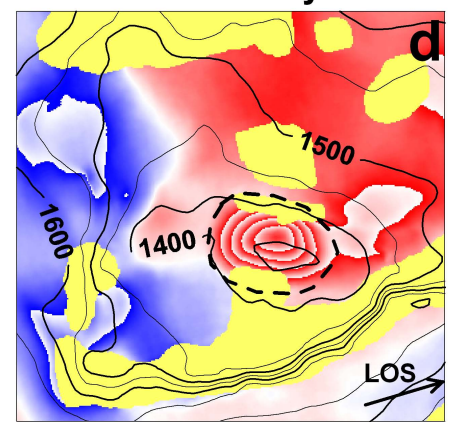

Fig. 4. (a-d) Topographically corrected interferograms of the Grímsvötn ice cover. White to blue fringes correspond to motion away from the satellites but white to red towards (LOS is indicated with an arrow). Broken lines indicate areas interpreted as the floating part of Grímsvötn ice cover. The yellow colour indicates areas where no usable interferometric measurements were obtained. (a) The average of two interferograms from ascending (looking eastward) and descending (looking westward) orbits, two days apart, before the Gjálp eruption. By combining interferograms from opposite radar look directions the contributions of the velocity component in east-west direction are almost completely cancelled out, making the rising and floating area more distinctive. Its border coincides with the $1480 \mathrm{~m}$ contour line, which according to GPS measurement matches the surface elevation of the floating ice cover at that time. (b-d) Interferograms from ascending orbits at three dates after the Gjálp eruption reveal much smaller floating area than in (a). Stars in (c) show the location of eruption sites in 1996 and 1998. Contours indicate elevation in August 1998 (Magnússon et al., 2005).

the variability of the surface melt rate is negligible. To make a legitimate comparison, we subtract from the net accumulation the estimated drainage from the Gjálp edifice, which otherwise would cause bias in all values from 1997 and later. Gudmundsson et al. (2002) estimated this drainage for 2122 May 1997, and values for December 1997 and February 2000 are from Jarosch et al. (2008), who estimated the average drainage from Gjálp at $5 \mathrm{~m}^{3} \mathrm{~s}^{-1}$ for the period June 1997 to June 1999 and $2 \mathrm{~m}^{3} \mathrm{~s}^{-1}$ from June 1999 to June 2001. For January and February 1999, close to the step in the melt rate curve from Jarosch et al., we use a more moderate value of $3 \mathrm{~m}^{3} \mathrm{~s}^{-1}$ instead of $5 \mathrm{~m}^{3} \mathrm{~s}^{-1}$. Having subtracted the drainage from Gjálp, the residual values, range from $-5 \mathrm{~m}^{3} \mathrm{~s}^{-1}$ to $1 \mathrm{~m}^{3} \mathrm{~s}^{-1}$ (Fig. 5) compared to $4-8 \mathrm{~m}^{3} \mathrm{~s}^{-1}$ prior to the Gjálp eruption. Assuming the same range of geothermal melt rate for Grímsvötn as observed from the InSAR data prior to the Gjálp eruption, these values indicate $3-13 \mathrm{~m}^{3} \mathrm{~s}^{-1}$ outflow from Grímsvötn for winter scenes from December 1997 to February 2000.
Electrical conductivity in rivers of southern and eastern Iceland above $100 \mu \mathrm{S} \mathrm{cm}^{-1}$ is considered an indicator of geothermal water component (S. R. Gislason, personal communication, 2008). The conductivity in the river Skeiðará, into which Grímsvötn drains, was measured on sub-daily basis during the month before the jökulhlaup in November 1996. The observations showed values of $60-120 \mu \mathrm{S} \mathrm{cm}^{-1}$ (Snorrason et al., 1997) with the highest values observed the last days before the jökulhlaup. The conductivity in the river outlet Skeiðará was typically $200-500 \mu \mathrm{S} \mathrm{cm}^{-1}$ during wintertime in 1997-2000 (Hydrological Service, 2008), even in January 1999, shortly before a small jökulhlaup from the lake, when the InSAR data suggest that the drainage was at minimum. This supports our interpretation of the leakage from Grímsvötn in winter time during our study period. During summers dilution by glacier surface melt makes conductivity measurements in the river Skeiðará inconclusive for identifying continuous leak of geothermal water from Grímsvötn. 


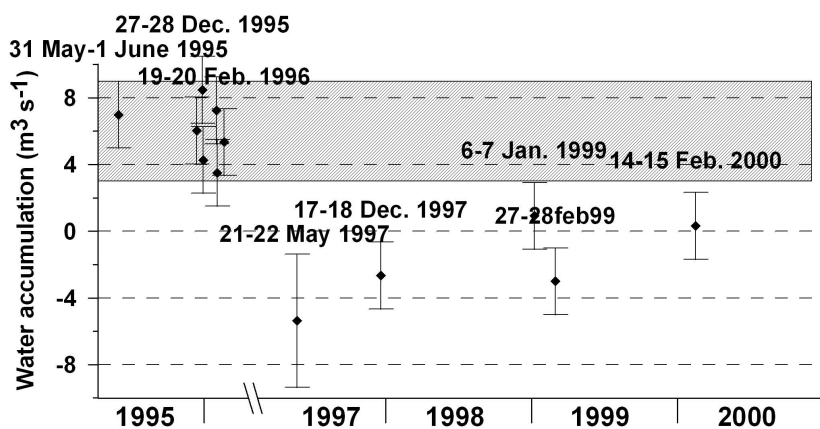

Fig. 5. The estimated water accumulation in lake Grímsvötn in winters derived from various interferograms, minus the estimated drainage produced during the cooling of the Gjálp edifice. The hatched area of the graph indicates the expected range of water accumulation $\left(6 \pm 3 \mathrm{~m}^{3} \mathrm{~s}^{-1}\right)$ in Grímsvötn during winters, assuming no leakage, based on the pre-jökulhlaup InSAR observations. Error bars are due to uncertainties in the estimated net water accumulation in Grímsvötn and the drainage from Gjálp.

\section{Discussion}

According to conventional concepts glacier basal sliding varies inversely with the effective basal pressure (the ice overburden pressure minus the water pressure) (e.g. Paterson, 2006). For glaciers with bed temperature at pressure melting point we can distinguish between two main types of drainage system with different water transport capacity and water pressure characteristics. First, a distributed drainage system of water filled cavities hydraulically interconnected by small orifices in which the water pressure increases with the flux (Walder, 1986). Second, a tunnel flow drainage system (Röthlisberger, 1972) which for steady state the water pressure relates inversely to the water flux. A switch from a distributed system to a tunnel flow drainage has been associated with the termination of a glacier surge (Kamb, 1987). A well established tunnel flow system has also been suggested to explain a minimum in glacier velocity concurrent to a record negative mass balance on Black Rapids glacier in Alaska (Truffer et al., 2005).

Based on our observations we suggest that water from Grímsvötn drained continuously through a tunnel underneath the glacier after the seal of the lake was damaged. The tunnel flow considerably reduced the subglacial water pressure in the vicinity of its flow path by draining water from the preexisting distributed drainage system of high water pressure, which sustained significant basal sliding when the lake was still sealed. The affected area was large enough to reduce the basal sliding significantly on a $\sim 5 \mathrm{~km}$ wide area on the upper part of the glacier and a $\sim 8 \mathrm{~km}$ wide area on the centre part (Figs. 2 and 3). The evolution of the glacier velocity towards its former state at the centre of the glacier took place during the reduced leakage from Grímsvötn at the end of our observation period (Figs. 2-3). The low subglacial water pressure, maintained by low drainage (few $\mathrm{m}^{3} \mathrm{~s}^{-1}$ ), constrained basal sliding of a $\sim 5 \mathrm{~km}$ wide glacier section throughout our study period in the upper part of the glacier.

The observations of a decrease in summer velocities are of particular interest. During summer we may expect high variation in basal water flow and the discharge-pressure relation for tunnel flow at steady state (Röthlisberger, 1972) would not apply. This has been demonstrated with observations by Hubbard et al. (1995), which were carried out in the ablation area of a glacier during late summer. The velocities observed from InSAR at cross-section I (Fig. 3), in the accumulation area of the glacier, show, however, little or no seasonal variation neither before nor after the 1996 jökulhlaup. This may be because the snow pack buffers the water flow from the surface to the base, maintaining stable basal water flow and pressure at the bed.

At cross-section II (Fig. 3), which is in the ablation area of the glacier, some seasonal variations were observed in the ice motion before the jökulhlaup. We have one velocity observation from 30-31 July 1997 in this area. At that time the fastest part of the cross-section flowed at $\sim 0.25 \mathrm{~m} \mathrm{~d}^{-1}$ compared to a typical winter velocity of $\sim 0.4 \mathrm{~m} \mathrm{~d}^{-1}$ in $1995-$ 1996, which may be referred to as the minimum velocity at this location before the 1996 jökulhlaup; summer velocities are normally higher (Fig. 3). We also have two observations from the summer 1999, which show similar velocities as observed during the winter 1995-1996 (Fig. 3).

The water drainage from the surface, passing crosssection II in July 1997, was approximately $\sim 300 \mathrm{~m}^{3} \mathrm{~s}^{-1}$ estimated as ablation in the drainage area above the cross-section for the summer 1997 (Björnsson and Pálsson, 2008), averaged over 3 months. Discrete GPS-data of the Grímsvötn ice cover from that time indicate that the lake was leaking at that time, but it is unlikely that this leak was more than $1 / 10$ of the water flow from the surface (see the interactive discussion for details). For simplification we may divide the water drainage, passing cross-section II, in three components; a) water transferred through a distributed drainage system b) slow-varying drainage through a tunnel (may be considered steady in a time scale of few days) and c) diurnal variations in the tunnel flow. In order to maintain low water pressure in this area a significant part of the water flow must contribute to the slow-varying tunnel drainage at crosssection II. It is unlikely that increasing b) by $\sim 30 \mathrm{~m}^{3} \mathrm{~s}^{-1}$, would have great impact on the water pressure in a drainage system with total discharge $\sim 300 \mathrm{~m}^{3} \mathrm{~s}^{-1}$. We suggest that the low pressure tunnel formed by the leakage drained water from the distributed drainage system in the vicinity of the leakage path, causing positive feedback in the slow-varying tunnel drainage. Component b) at cross section II was therefore higher than the sum of the leakage and the non-varying tunnel discharge at cross section II prior to the onset of the leakage.

To enable modelling of the lateral pressure reduction at the glacier bed produced by the leakage from the lake and 
the consequent reduction in basal sliding, a two dimensional model of coupled tunnel and distributed water system is required. For such modelling more data on the pre-existing drainage system in the leakage path and various other parameters are needed. The outcome of such a model would not necessarily be more conclusive than the presented results due to its complexity and lack of constraints. Our observation should, however, be considered when expanding one dimensional models of coupled tunnel and distributed water system (e.g. Flowers, 2008) into two dimensional models. The parameters determining the coupling of the water pressure in the tunnel and the distributed water system and the water exchange between these systems may be constrained with our observations for two dimensional models.

Our observations may have relevance to considerations of how increase in meltwater may influence the ice flow of the Greenland ice sheet (Zwally et al., 2002). The relevance to other leaking subglacial lakes (e.g. Fricker et al., 2007) underneath warm based glacier would depend on whether the leakage is continuous or pulsed and on the water pressure of the pre-existing drainage system.

\section{Conclusions}

A jökulhlaup from the subglacial lake Grímsvötn in Vatnajökull damaged the lake's ice dam, and thus produced a rare opportunity to observe the effects of changing pattern of subglacial water flow on basal sliding. InSAR observations suggest that a leakage of $>3 \mathrm{~m}^{3} \mathrm{~s}^{-1}$ prevailed throughout our study period (1995-2000). The presented InSAR observations show $\sim 50 \%$ reduction in glacier velocity above the estimated flow route from Grímsvötn subsequent to the jökulhlaup. The velocity remained low in the upper part of the glacier throughout our study period, but the centre part had reached the pre-jökulhlaup velocity in January 2000.

In accordance with current understanding that basal sliding varies inversely with the effective basal pressure and that onset of steady state tunnel flow is likely to reduce the basal water pressure (Röthlisberger, 1972; Kamb, 1987), our observations suggest that the continuous water drainage from Grímsvötn formed tunnel flow at low water pressure. The reduction in water pressure propagated laterally from the tunnel over a distance of few $\mathrm{km}$, reducing the basal sliding of an area of $\sim 5 \mathrm{~km}$ width in the upper part and $\sim 8 \mathrm{~km}$ in the centre part of the glacier.

Acknowledgements. The ERS1/2 tandem data were made available by ESA through projects AO3.108 (VECTRA) and AO3.239. The EMISAR-DEM from 1998 was used by courtesy of National Space Institute, DTU, Denmark. This work was supported by the Bertha von Suttner Foundation, the Icelandic Centre for Research, Landsvirkjun the Memorial Foundation of Helga Jónsdóttir and Sigurliði Kristjánsson and the Icelandic Road Administration. We thank Thomas Nagler and Florian Müller for their help with the processing of the InSAR data. Freysteinn Sigmundsson,
Magnús T. Guðmundsson and Alexander H. Jarosch are thanked for access to computational power and Sverrir Guðmundsson for valuable advice regarding numerical calculations. Einar Sveinbjörnsson is thanked for providing temperature data. We thank Doug Benn, Mauri Pelto and an anonymous reviewer for constructive reviews.

Edited by: J. Moore

\section{References}

Anderson, R. S., Walder, J. S., Anderson, S. P., Trabant, D. C., and Fountain, A. G.: The dynamic response of Kennicott Glacier, Alaska, USA, to the Hidden Creek Lake outburst flood, Ann. Glaciol., 40, 237-242, 2005.

Bacher, U., Bludovsky, S., Dorrer E., and Münzer, U.: Precision aerial survey of Vatnajökull, Iceland by digital photogrammetry, in: Proceedings of Third Turkish-German Joint Geodetic Days -Towards a Digital Age, edited by: Oltan, M. O. and Gründig, L., Istanbul Tech. Univ., Istanbul, 1-10, 1999.

Bartholomaus, T. C., Anderson, R. S., and Anderson, S. P.: Response of glacier motion to transient water storage, Nature Geosci., 1, 33-37, 2008.

Berthier, E., Björnsson, H., Pálsson, F., Feigl, K. L., Llubes, M., and Rémy, F.: The level of the Grimsvötn subglacial lake, Vatnajökull, Iceland, monitored with SPOT5 images, Earth Planet. Sc. Lett., 243, 293-302, 2006.

Björnsson, H.: Subglacial lakes and jökulhlaups in Iceland, Global Planet. Change, 35, 255-271, 2002.

Björnsson, H. and Gudmundsson, M. T.: Variations in the thermal output of the subglacial Grímsvötn caldera, Iceland, Geophys. Res. Lett., 20, 2127-2130, 1993.

Björnsson, H. and Pálsson, F.: Icelandic glaciers, Jökull, 58, 365386, 2008.

Flowers, G. E.: Subglacial modulation of the hydrograph from glacierized basins, Hydrol. Process., 22(19), 3903-3918, 2008.

Fricker, H. A., Scambos, T., Bindschadler, R., and Padman, L.: An Active Subglacial Water System Mapped from Space, Science, 315, 1544-1548, 2007.

Gudmundsson, M. T.: Subglacial volcanic activity in Iceland, in: Iceland - Modern Processes and past environments, edited by: Caseldine, C., Russel, A., Hardardóttir, J., and Knudsen, Ó., Developments in Quaternary Science, 5, 127-151, 2005.

Gudmundsson, M. T., Sigmundsson, F., and Björnsson, H.: Icevolcano interaction of the 1996 Gjálp subglacial eruption, Vatnajökull, Iceland, Nature, 389, 954-957, 1997.

Gudmundsson, S., Gudmundsson, M. T., Björnsson, H., Sigmundsson, F., Rott, H., and Carstensen, J. M.: Three-dimensional glacier surface motion maps at the Gjálp eruption site, Iceland, inferred from combining InSAR and other ice-displacement data, Ann. Glaciol., 34, 315-322, 2002.

Hanssen, F. R.: Radar Interferometry -Data Interpretation and Error Analysis, Kluwer Academic Publishers, Dordrecht, The Netherlands, 328 pp., 2001.

Hubbard, B. P., Sharp, M. J., Willis, I. C., Nielsen, M. K., and Smart, C. C.: Borehole water-level variations and the structure of the subglacial hydrological system of Haut Glacier D' Arolla, Valais, Switzerland, J. Glaciol., 44(139), 572-583, 1995. 
Hydrological Service, Orkustofnun: Delivery of data from the database of the Hydrological Service, Orkustofnun, Iceland, no. 2008/33, 2008.

Iken, A.: Variations of surface velocities of some Alpine glaciers measured at intervals of a few hours, Comparison with artic glaciers, Zeitschrift für Gletscherkunde und Glazialgeologie, 13, 23-35, 1978.

Jarosch, A. H., Gudmundsson, M. T., Högnadóttir, Th., and Axelsson, G.: The progressive cooling of the hyaloclastite ridge at Gjálp, Iceland, 1996-2005, J. Volcanol. Geotherm. Res., 170, 218-229, 2008.

Kamb, B.: Glacier surge mechanism based on linked cavity configuration of the basal water conduit system, J. Geophys. Res., 92, 9083-9100, 1987.

Magnússon, E.: Glacier hydraulics explored by means of SARinterferometry, (Ph.D. thesis, Leopold-Franzens-Universität Innsbruck), 107 pp., 2008.

Magnússon, E., Björnsson, H., Dall, J., and Pálsson, F.: Volume changes of Vatnajökull ice cap, Iceland, due to surface mass balance, ice flow, and subglacial melting at geothermal areas, Geophys. Res. Lett., 32, L05504, doi:10.1029/2004GL021615, 2005.

Magnússon, E., Rott, H., Björnsson, H., and Pálsson, F.: The impact of jökulhlaups on basal sliding observed by SAR Interferometry on Vatnajökull, Iceland, J. Glaciol., 53(181), 232-240, 2007.

Paterson, W. S. B.: The Physics of Glaciers, 3rd ed., ButtenworthHeinemann, Oxford, UK, 481 pp., 2006.
Reeh, N., Mohr, J. J., Madsen, S. N., Oerter, H., and Gundestrup, N. S.: Three-dimensional surface velocity of Storstrømmen glacier, Greenland, derived from radar interferometry and ice-sounding radar measurements, J. Glaciol., 49(165), 201-209, 2003.

Röthlisberger, H.: Water pressure in intra- and subglacial channels, J. Glaciol., 11(62), 177-203, 1972.

Snorrason, Á., Jónsson, P., Pálsson, S., Árnason, S., Sigurdsson, O., Víkingsson, S., Sigurdsson Á., and Zóphóníasson, S.: Hlaupið á Skeiðarársandi haustið 1996, Vatnajökull gos og hlaup, edited by: Haraldsson, H., Icel. Public Roads Admin., Reykjavík, Iceland, 79-137, 1997.

Sugiyama, S. and Gudmundsson, G. H.: Short-term variations in glacier flow controlled by subglacial water pressure at Lauteraargletscher, Bernese Alps, Switzerland, J. Glaciol., 50(170), 353362, 2004.

Truffer, M., Harrison, W. D., and March, R. S.: Correspondence - Record negative glacier balance and low velocities during the 2004 heat wave in Alaska, USA: implications for the interpretation of observations by Zwally et al. in Greenland, J. Glaciol., 51(175), 663-664, 2005.

Walder, J. S.: Hydraulics of subglacial cavities, J. Glaciol., 32(112), 439-445, 1986.

Willis, I. C.: Intra-annual variations in glacier motion: a review, Progress in Physical Geography, 19, 61-106, 1995.

Zwally, H. J., Abdalati, W., Herring, T., Larson, K., Saba, J., and Steffen, K.: Surface Melt-Induced Acceleration of Greenland Ice-Sheet Flow, Science, 297, 218-222, 2002. 